\title{
Comparison of adequacy of endometrial biopsy using endosampler and hysteroscope guided sampling
}

\author{
Vijay Zutshi, Asmita Saran*, Charanjeet Ahluwalia
}

Department of Obstetrics and Gynecology, Vardhaman Mahavir Medical College and Safdarjung Hospital, New Delhi, India

Received: 28 March 2021

Accepted: 29 April 2021

\section{*Correspondence:}

Dr. Asmita Saran,

E-mail: asmitasaran11@gmail.com

Copyright: (C) the author(s), publisher and licensee Medip Academy. This is an open-access article distributed under the terms of the Creative Commons Attribution Non-Commercial License, which permits unrestricted non-commercial use, distribution, and reproduction in any medium, provided the original work is properly cited.

\section{ABSTRACT}

Background: The objective of the study was to compare the tissue adequacy of endometrial biopsy obtained using hysteroscope guided biopsy and endosampler for histopathology.

Methods: This was a cross sectional study in the Department of Obstetrics and Gynaecology and Pathology, Medical College Hospital, New Delhi, India. Ninety patients fulfilling the inclusion criteria were subjected to office hysteroscope guided biopsy followed by endometrial aspiration biopsy using endosampler in the same sitting. Labelling of samples was done as ' $\mathrm{A}$ ' and ' $\mathrm{B}$ ' and sent for histopathological examination in 10\% formalin. Pathologist was blinded to the type of biopsy taken and samples were evaluated for tissue adequacy. The presence of even one intact endometrial gland with stroma was labelled as adequate endometrial biopsy sample by the pathologist.

Results: The endometrial biopsy samples obtained by both methods were adequate in 35 patients $(38.89 \%)$. On the other hand, there were 18 patients $(20 \%)$ who had inadequate sampling results by both methods. Out of the remaining 37 patients, in $13(14.44 \%)$ patient's endometrial biopsy was adequate by hysteroscope guided biopsy and in 24 $(26.67 \%)$ patients it was adequate using endometrial aspiration Individually, hysteroscope guided biopsies were found to have adequate results in 48 patients out of $90(53.33 \%)$ while endosampler aspiration provided adequate biopsy results in 59 patients out of $90(65.56 \%)$ after excluding the number of patients having inadequate reports. The difference between tissue adequacy of both devices was not statistically significant $(\mathrm{p}=0.129)$. A significant correlation was found between age $(\mathrm{p}<0.001)$, endometrial thickness on ultrasound $(\mathrm{p}<0.0001)$ and tissue adequacy by both methods.

Conclusions: Endometrial biopsy obtained by hysteroscope guided method and endometrial aspiration was comparable in terms of tissue adequacy.

Keywords: Hysteroscope, Endosampler

\section{INTRODUCTION}

Endometrial sampling is one of the most common gynaecological procedure carried out in patients with abnormal uterine bleeding and infertility. The methods of endometrial sampling are unguided and guided. The reported sensitivity and specificity of various unguided methods of endometrial sampling like Novak curette, Vabra aspirator, pipelle aspirator, endosampler are $57 \%$ and $97 \%, 88.2 \%$ and $88.7 \%, 60-100 \%$ and $51.4-100 \%$, $93 \%$ and $100 \%$ respectively while the sensitivity and specificity of guided endometrial biopsy using hysteroscopy is $100 \%$ and $72.8-91 \% .^{1-15}$

The endometrial biopsy obtained by any method of endometrial sampling should provide adequate tissue for proper histopathological diagnosis. One of the common challenges for sampling procedures is obtaining sufficient amount of tissue for diagnosis, especially in the postmenopausal women. Sometimes the tissue obtained is so small that the pathologists report it as insufficient for 
diagnosis. It has been reported that in 2 to $60 \%$ of the cases insufficient endometrial samples are obtained. ${ }^{16}$

The tissue adequacy depends upon size and morphogenic features (like number and height of intact endometrial glands with stroma) of the sample obtained. The exact criteria for tissue adequacy is still not well defined. The criteria proposed by Kandil et al states that in premenopausal women at least one intact endometrial fragment is required to evaluate the gland to stroma ratio while for postmenopausal woman 5 to 10 strips of endometrial epithelium with or without stroma are required to comment on tissue adequacy. ${ }^{16}$

A consensus recommendation published in a commentary on the management of endometrial precancers stated that devices that yielded crushed (jawed devices) or very small (jawed devices) samples were not reliable in terms of tissue adequacy. ${ }^{17}$

Common observation is that the size of biopsy obtained by hysteroscope guided technique is very small as compared to that obtained by unguided methods like endosampler due to the small diameter of grasping biopsy forceps. The objective of this study was to find out whether hysteroscope guided biopsy (obtained using jawed biopsy forceps) provided adequate tissue in comparison to endosampler aspiration.

\section{METHODS}

This cross-sectional study was performed between 2017 to 2019 in a Medical college hospital of Delhi, India. Ninety patients with AUB and infertility fulfilling the inclusion criteria were enrolled and patients with genital infections, other chronic medical or surgical illness leading to AUB were excluded, and the protocol was approved by the ethics committee of the institute.

A detailed history and clinical examination was done after written informed consent. Endometrial biopsy was done in the minor gynecology operation theatre. A tablet containing a combination of $400 \mathrm{mg}$ ibuprofen and $325 \mathrm{mg}$ paracetamol was given to all study subjects 45 minutes prior to endometrial biopsy.

Hysteroscopy was done using office hysteroscope, endometrial cavity was examined and guided biopsy was taken if any suspicious looking area was seen, otherwise random endometrial biopsy was taken, later endosampler was used for taking endosampler aspiration biopsy. Both the procedures were performed in the same sitting.

The hysteroscope used in our study was a $0^{\circ}$ scope with a $4 \mathrm{~mm}$ inner sheath diameter and a length of $22 \mathrm{~cm}$. A $5 \mathrm{fr}$ biopsy forceps was used for taking guided endometrial biopsy.

The endosampler used in the study was a low-pressure endometrial sampling device, $23 \mathrm{~cm}$ in length and $3 \mathrm{~mm}$ in diameter. The negative pressure was created by a $10 \mathrm{ml}$ syringe and the endometrial aspirate obtained.

All the samples obtained were preserved in $10 \%$ formalin. Biopsy obtained by hysteroscope was labelled as ' $\mathrm{A}$ ' and biopsy obtained by endosampler was labelled as ' $\mathrm{B}$ '. The samples were sent for histopathological evaluation but pathologist was blinded to the method of obtaining biopsy. The criteria used by pathologists in our institute regarding tissue adequacy was the presence of at least a single intact endometrial gland with stroma.

\section{Sample size calculation}

On the basis of previous studies around $13 \%$ of tissue samples were inadequate in hysteroscope guided biopsies and $7 \%$ in the specimens obtained by endometrial aspiration techniques. ${ }^{10,11,18}$ Taking this value as reference, the minimum required sample size with $7.5 \%$ margin of error and $5 \%$ level of significance is 78 patients. So total sample size calculated was 80 .

The total sample size taken in the study is 90 .

Formula used in this study was

$$
N \geq \frac{p(1-p)}{\left(\frac{M E}{Z_{\alpha}}\right)^{2}}
$$

Where,

$\mathrm{Z}_{\alpha}$ is value of $\mathrm{Z}$ at two-sided alpha error of $5 \%$, $\mathrm{ME}$ is margin of error and $\mathrm{p}$ is proportion of adequate samples.

\section{Type of study}

The type of study was cross sectional study.

\section{Statistical analysis}

Categorical variables were presented in number and percentage $(\%)$ and continuous variables were presented as mean \pm SD and median. Normality of data was tested by Kolmogorov-Smirnov test. If the normality was rejected then non-parametric test was used.

Statistical tests were applied as follows- (a) quantitative variables were compared using independent t test/MannWhitney test (when the data sets were not normally distributed) between the two groups and (b) qualitative variables were correlated using chi-square test/Fisher's exact test. $\mathrm{P}$ value of $<0.05$ was considered statistically significant.

The data was entered in Microsoft excel spreadsheet and analysis was done using statistical package for social sciences (SPSS) version 21.0. 


\section{RESULTS}

Clinical characteristics and histopathology report depicted in Table 1 shows that the maximum number of patients were in the age group of 40-50 years with the mean age of 44.3 years and maximum patients were multiparous with mean parity of 2.7 .

Around 53.33\% women had presented with complains of heavy menstrual bleeding. On evaluating the endometrial thickness by ultrasound, 70\% (63) patients had ET >4 mm while for the remaining patients ET was $\leq 4 \mathrm{~mm}$. The hysteroscopic findings were found to be normal in $37.78 \%$ patients and polyps were detected in $26.67 \%$ patients. The size of the biopsy obtained using hysteroscope guided method was in the range of $0.001-0.002 \mathrm{~cm}^{3}$ (mean size$0.0015 \mathrm{~cm}^{3}$ ) in $62.22 \%$ patients and that obtained by endometrial aspiration was in the range of 0.011-0.1 $\mathrm{cm}^{3}$ (mean size- $0.055 \mathrm{~cm}^{3}$ ) in $33.33 \%$ patients. On histopathological evaluation, more than $50 \%$ of the patients had proliferative endometrium (Table 1).

Table 1: Adequacy of endometrial biopsy.

\begin{tabular}{|c|c|c|c|c|c|}
\hline Factors & $\begin{array}{l}\text { Number } \\
(\%)\end{array}$ & Number (\%) & Number (\%) & Number (\%) & Number (\%) \\
\hline Age (years) & $\begin{array}{l}21-30 \\
(11.11)\end{array}$ & $\begin{array}{l}31-40 \\
(24.44)\end{array}$ & $\begin{array}{l}41-50 \\
(47.78)\end{array}$ & $\begin{array}{l}51-60 \\
(12.22)\end{array}$ & $\begin{array}{l}>60 \\
(4.44)\end{array}$ \\
\hline Parity & $\begin{array}{l}\text { (Nulliparous) } \\
2\end{array}$ & $\begin{array}{l}\text { (Primiparous) } \\
8\end{array}$ & $\begin{array}{l}\text { (Multiparous) } \\
80\end{array}$ & - & \\
\hline Chief complaints & $\begin{array}{l}\left(\mathrm{Hmb}^{*}\right) \\
48\end{array}$ & $\begin{array}{l}\left(\operatorname{Imb} b^{*}\right) \\
22\end{array}$ & $\begin{array}{l}\left(\mathrm{Pmb}^{*}\right) \\
18\end{array}$ & $\begin{array}{l}\text { (Infertility) } \\
2\end{array}$ & \\
\hline $\begin{array}{l}\text { Clinical findings } \\
\text { on per vaginal } \\
\text { examination }\end{array}$ & $\begin{array}{l}\text { (Uterus } \\
\text { normal size) } \\
81\end{array}$ & $\begin{array}{l}\text { (Uterus } \\
\text { bulky) } \\
5\end{array}$ & $\begin{array}{l}\text { (Uterus 6-8 } \\
\text { weeks) } \\
4\end{array}$ & - & \\
\hline $\begin{array}{l}\text { ET on USG } \\
\text { (in } \mathbf{~ m m} \text { ) }\end{array}$ & $\begin{array}{l}(\leq 4 \mathrm{~mm}) \\
63\end{array}$ & $\begin{array}{l}(>4 \mathrm{~mm}) \\
27\end{array}$ & - & - & \\
\hline $\begin{array}{l}\text { Hysteroscopic } \\
\text { findings }\end{array}$ & $\begin{array}{l}\text { (Normal) } \\
34\end{array}$ & $\begin{array}{l}\text { (Polyp) } \\
24\end{array}$ & $\begin{array}{l}\text { (Fibroid) } \\
18\end{array}$ & $\begin{array}{l}\text { (Hyperplasia } \\
\text { ) } 11\end{array}$ & $\begin{array}{ll}\text { (Subseptate) } & \text { (Calcification) } \\
2 & 1\end{array}$ \\
\hline $\begin{array}{l}\text { Size of } \\
\text { endometrial } \\
\text { biopsy using } \\
\text { hysteroscope in } \\
\text { mm }^{3}\end{array}$ & $\begin{array}{l}(0.001-0.002) \\
56\end{array}$ & $\begin{array}{l}(0.003-0.006) \\
13\end{array}$ & $\begin{array}{l}(0.007-0.010) \\
4\end{array}$ & $\begin{array}{l}(0.011-0.1) \\
12\end{array}$ & $\begin{array}{l}(0.101-1) \\
5\end{array}$ \\
\hline $\begin{array}{l}\text { Size of } \\
\text { endometrial } \\
\text { biopsy using } \\
\text { endosampler in } \\
\text { mm }^{3}\end{array}$ & $\begin{array}{l}(0.001-0.002) \\
17\end{array}$ & $\begin{array}{l}(0.003-0.006) \\
13\end{array}$ & $\begin{array}{l}(0.007-0.010) \\
10\end{array}$ & $\begin{array}{l}(0.011-0.1) \\
30\end{array}$ & $\begin{array}{l}(0.101-4) \\
20\end{array}$ \\
\hline $\begin{array}{l}\text { Histopathological } \\
\text { findings }\end{array}$ & $\begin{array}{l}\text { (Proliferative } \\
\text { endometrium) } \\
39\end{array}$ & $\begin{array}{l}\text { (Secretory } \\
\text { endometrium) } \\
27\end{array}$ & $\begin{array}{l}\text { (Hyperplastic } \\
\text { endometrium) } \\
4\end{array}$ & $\begin{array}{l}\text { (Atrophic } \\
\text { endometriu } \\
\text { m) } 1\end{array}$ & $\begin{array}{l}\text { (Chronic endometrium) } \\
1\end{array}$ \\
\hline $\begin{array}{l}\text { Hysteroscopic } \\
\text { findings }\end{array}$ & $\begin{array}{l}\text { (Normal) } \\
34\end{array}$ & $\begin{array}{l}\text { (Polyp) } \\
24\end{array}$ & $\begin{array}{l}\text { (Fibroid) } \\
18\end{array}$ & $\begin{array}{l}\text { (Hyperplasia) } \\
11\end{array}$ & $\begin{array}{ll}\text { (Subseptate) } & \text { (Calcification) } \\
2 & 1\end{array}$ \\
\hline $\begin{array}{l}\text { Size of } \\
\text { endometrial } \\
\text { biopsy using } \\
\text { hysteroscope in } \\
\text { mm }^{3}\end{array}$ & $\begin{array}{l}(0.001-0.002) \\
56\end{array}$ & $\begin{array}{l}(0.003-0.006) \\
13\end{array}$ & $\begin{array}{l}(0.007-0.010) \\
4\end{array}$ & $\begin{array}{l}(0.011-0.1) \\
12\end{array}$ & $\begin{array}{l}(0.101-1) \\
5\end{array}$ \\
\hline $\begin{array}{l}\text { Size of endometrial } \\
\text { biopsy using } \\
\text { endosampler in } \mathrm{mm}\end{array}$ & $\begin{array}{l}(0.001-0.002) \\
17\end{array}$ & $\begin{array}{l}(0.003-0.006) \\
13\end{array}$ & $\begin{array}{l}(0.007-0.010) \\
10\end{array}$ & $\begin{array}{l}(0.011-0.1) \\
30\end{array}$ & $\begin{array}{l}(0.101-4) \\
20\end{array}$ \\
\hline $\begin{array}{l}\text { Histopathological } \\
\text { findings }\end{array}$ & $\begin{array}{l}\text { (Proliferative } \\
\text { endometrium) } \\
39\end{array}$ & $\begin{array}{l}\text { (Secretory } \\
\text { endometrium) } \\
27\end{array}$ & $\begin{array}{l}\text { (Hyperplastic } \\
\text { endometrium) } \\
4\end{array}$ & $\begin{array}{l}\text { (Atrophic } \\
\text { endometriu } \\
\mathrm{m} \text { ) } \\
1\end{array}$ & $\begin{array}{l}\text { (Chronic endometrium) } \\
1\end{array}$ \\
\hline
\end{tabular}

*Hmb- heavy menstrual bleeding, Imb- irregular menstrual bleeding, $\mathrm{Pbm}$ - post menstrual bleeding 
Regarding adequacy of endometrial biopsy, Table 2 shows that it was adequate in 35 patients $(38.89 \%)$ and inadequate in 18 patients $(28 \%)$ by both methods. Out of the rest 37 women, in 24 women endometrial biopsies were inadequate by hysteroscope guided method but adequate by endosampler method. In the remaining 13 women endometrial biopsy was inadequate by endosampler but adequate by hysteroscope guided method. The number of patients who had adequate biopsy results by hysteroscope guided method and inadequate by endosampler were $14.4 \%$ out of which majority (69.2\%) were focal lesions, and those having adequate results by endosampler and inadequate results by hysteroscope guided biopsy were $26.67 \%$ out of which $50 \%$ were focal lesions (Table 2).

Table 2: Adequacy of endometrial biopsy.

\begin{tabular}{|lll|}
\hline Tissue adequacy of endometrial biopsy & Number & Percentage $(\%)$ \\
\hline Adequate by both devices & 35 & 38.89 \\
\hline Inadequate by both devices & 18 & 20.00 \\
\hline Adequate in hysteroscope guided biopsy and inadequate in EA & $13(69.2=\mathrm{F})$ & 14.44 \\
\hline Inadequate in hysteroscope guided biopsy and adequate in EA* & $24(50=\mathrm{F})$ & 26.67 \\
\hline Total & 90 & 100.00 \\
\hline
\end{tabular}

*EA-endometrial aspiration, $\mathrm{F}=$ focal lesions

Correlating adequacy of endometrial biopsy with various parameters (Table 3), the endometrial biopsy samples were adequate in $71.43 \%$ women between the age group of 22 45 years while it was adequate in only $28.47 \%$ cases in the age group of $>45$ years by both devices. Out of 35 patients in the age group of $>45$ years, 18 were post-menopausal and the rest 17 were pre-menopausal. The tissue adequacy of endometrial biopsy decreased as the age advanced which showed a statistically significant correlation ( $p$ value<0.0001). The maximum number of cases with adequate biopsy results by both devices were of heavy menstrual bleeding $(68.57 \%)$ and minimum were of postmenopausal bleeding $(5.71 \%)$. Regarding endometrial thickness on ultrasound, endometrial biopsy was adequate in $91.43 \%$ patients when ET was $>4 \mathrm{~mm}$. The correlation observed between the endometrial thickness on ultrasound and tissue adequacy was significant with a $\mathrm{p}$ value of $<0.0001$.

Table 3: Correlation of tissue adequacy with respect to various factors.

\begin{tabular}{|c|c|c|c|c|}
\hline Factors & Classification & $\begin{array}{l}\text { Adequate by both } \\
\text { methods }\end{array}$ & $\begin{array}{l}\text { Inadequate by } \\
\text { both methods }\end{array}$ & P value \\
\hline \multirow{2}{*}{ Age (years) } & $22-45$ & 25 & 4 & \multirow{2}{*}{0.001} \\
\hline & $>45$ & 10 & 14 & \\
\hline \multirow{3}{*}{ Parity } & Nulliparous & - & - & \multirow{3}{*}{0.56} \\
\hline & Primiparous & 2 & 2 & \\
\hline & Multiparous & 33 & 16 & \\
\hline \multirow{4}{*}{ Clinical indications } & $\mathrm{Hmb}^{*}$ & 24 & 6 & \multirow{4}{*}{$<0.0001$} \\
\hline & $\mathrm{Imb}^{*}$ & 9 & 1 & \\
\hline & $\mathrm{Pmb}^{*}$ & 2 & 11 & \\
\hline & Infertility & - & - & \\
\hline \multirow{2}{*}{ ET on USG (mm) } & $\leq 4 \mathrm{~mm}$ & 3 & 18 & \multirow{2}{*}{$<0.0001$} \\
\hline & $>4 \mathrm{~mm}$ & 32 & 0 & \\
\hline \multirow{6}{*}{ Hysteroscopic findings } & Normal & 12 & 12 & \multirow{6}{*}{0.12} \\
\hline & Polyp & 12 & 3 & \\
\hline & Fibroid & 8 & 1 & \\
\hline & Hyperplasia & 3 & 2 & \\
\hline & Subseptate & - & - & \\
\hline & Calcification & - & - & \\
\hline
\end{tabular}

On taking endometrial biopsy by hysteroscopic guided method, the biopsy tissue was adequate in 48 patients $(55.3 \%)$ while biopsy was adequate in 59 patients $(65.56 \%)$ when endometrial biopsy was taken by endometrial aspiration techniques.
The difference in the tissue adequacy of endometrial biopsy by both these methods was not found to be statistically significant $(\mathrm{p}$ value $=0.129)($ Table 4$)$. 
Table 4: Comparison of tissue adequacy of hysteroscope guided biopsy with endometrial aspiration biopsy.

\begin{tabular}{|lll|l}
$\begin{array}{|lll|}\text { Tissue } \\
\text { adequacy }\end{array}$ & $\begin{array}{l}\text { Hysteroscope } \\
\text { guided biopsy } \\
(\%)\end{array}$ & $\begin{array}{l}\text { Endosampler } \\
\text { aspiration } \\
(\%)\end{array}$ & $\begin{array}{l}\text { P } \\
\text { value }\end{array}$ \\
\cline { 1 - 2 } Adequate & $48(53.33)$ & $59(65.56)$ & \\
\cline { 1 - 2 } Inadequate & $42(46.67)$ & $31(34.44)$ & 0.129 \\
\cline { 1 - 2 } Total & $90(100.00)$ & $90(100.00)$ & \\
\cline { 1 - 2 }
\end{tabular}

\section{DISCUSSION}

There are various sampling devices available for obtaining endometrial biopsy and the ultimate aim of the procedure is to obtain adequate tissue sample for reporting which is important for further management.

Hysteroscopic guided biopsy is advocated as an ideal method. However, this facility may not be available in many places specially in low resource settings. The concensus recommendation published in a commentary on the management of endometrial precancers stated that devices that yielded crushed (jawed devices) or very small (jawed devices) samples were not reliable in terms of tissue adequacy. ${ }^{17}$ The criteria used for reporting adequate tissue has not been clearly defined. In our study pathologist used the criteria of intact gland with stroma. Various studies have also emphasized the presence of intact gland in reporting tissue adequacy. ${ }^{16,19}$

In our study the size of endometrial biopsy obtained using hysteroscope guided method was in the range of 0.001 $0.002 \mathrm{~cm}^{3}$ (mean size- $0.0015 \mathrm{~cm}^{3}$ ) in $62.22 \%$ of patients and for endometrial aspiration biopsy it was $0.011-0.1 \mathrm{~cm}^{3}$ (mean size- $0.055 \mathrm{~cm}^{3}$ ) in $33.33 \%$ of patients. The size of endometrial biopsy obtained using hysteroscope guided method was comparatively smaller than the size of biopsy obtained using endosampler due to smaller diameter of the grasping forceps used in the procedure.

From our results it became evident that the size of endometrial biopsy did not affect the tissue adequacy ( $p>0.05)$ which meant that the number of intact glands to stroma ratio mattered more than simply the size of endometrial biopsy obtained. No published literature is available on this issue, with which we could compare our results.

Hysteroscopy guided biopsy has been used in various clinical conditions to study sensitivity and specificity but there are very few studies where tissue adequacy has been reported using hysteroscope guided biopsy. ${ }^{12-15}$

Comparison of hysteroscope guided biopsy with other sampling devices in terms of tissue adequacy has not been extensively studied.

A prospective observational study on 150 perimenopausal women with AUB, showed both hysteroscope guided biopsy and pipelle biopsy to be comparable in terms of tissue adequacy. ${ }^{20}$ In this study further it was stated that the hysteroscope guided biopsy diagnosed more cases of hyperplasia as compared to those diagnosed by pipelle, but this marginal difference was not statistically significant. Another similar study where endometrial tissue was obtained by both hysteroscope guided biopsy and pipelle aspiration in 130 women with AUB and both the methods proved to have a comparable tissue adequacy. ${ }^{15}$

We found adequate tissue in $53.33 \%$ and $66.67 \%$ of the patients by hysteroscope guided biopsy and endosampler aspiration respectively. Although endosampler endometrial biopsy reported a higher percentage of tissue adequacy but this difference was not statistically significant ( $p$ value $=0.126$ ) and was comparable to above mentioned studies. These observations reiterates the fact that endometrial biopsy can be obtained adequately by sampling devices other than hysteroscope.

There are variable reports addressing the adequacy of endometrial biopsy related to age.

On comparing tissue adequacy with other demographic parameters, we found that out of 90 patients 43 patients were in the age group of 41-50 years. A statistically significant correlation was found between age and tissue adequacy which implied that more the age ( $>45$ years) less is the tissue adequacy ( $\mathrm{p}$ value $=0.001$ ).

Bakour et al in their univariate analysis on 248 women with AUB reported that chances of inadequate tissue specimen increased with increasing age $(p$ value $=0.001){ }^{21}$ Similarly Dina Kandil et al in their retrospective study on 17522 women reported an inverse correlation between age and tissue adequacy. ${ }^{16}$ In contrast some other studies showed no significant correlation between age and tissue adequacy. ${ }^{16,22}$ The probable reason in these two studies could be variable distribution of patients in the various age spectrums and also that the data was analysed retrospectively.

The first step in evaluation of AUB is the assessment of thickness of endometrium by TVS.

We observed that the thickness of endometrium on ultrasound in $\mathrm{mm}$ was directly related to adequacy of endometrial biopsy. Of the 90 patients, 63 patients $(70 \%)$ were having endometrial thickness of $>4 \mathrm{~mm}$ and out of these 32 patients had been adequately sampled by both methods. In the remaining 27 patients of endometrial thickness $\leq 4 \mathrm{~mm}, 18(66.67 \%)$ patients had inadequate biopsy reports. It was inferred from these findings that thickness of endometrium $(>4 \mathrm{~mm})$ was directly correlating with tissue adequacy ( $\mathrm{p}$ value $<0.0001)$. Similar results were reported in a study by Aue et al in a prospective study done on 233 patients where a statistical correlation was seen between endometrial thickness and tissue adequacy. ${ }^{22}$ 
Various other studies have also established that the endometrial thickness is directly related to tissue adequacy. ${ }^{22,23}$

On the contrary some studies found no significant correlation between endometrial thickness and tissue adequacy because of exclusion of patients with ET $\leq 4 \mathrm{~mm}$ and influence by other secondary factors like type of device, type of provider and uterine volume etc. ${ }^{24,25}$

The strength of our study is that it is the first study to compare hysteroscope guided biopsy and endosampler aspiration in terms of tissue adequacy. There is no observer bias as both procedures were conducted by the same observer in the same setting. The limitation of our study was that since no previous studies have been conducted comparing tissue adequacy of hysteroscope guided biopsy with endosampler, we could not compare our results.

\section{CONCLUSION}

For obtaining adequate endometrial biopsy, endometrial aspiration by endosampler and hysteroscope guided biopsy, both are comparable.

Funding: No funding sources

Conflict of interest: None declared

Ethical approval: The study was approved by the Institutional Ethics Committee

\section{REFERENCES}

1. Seamark CJ. The demise of the D\&C. J R Soc Med. 1998;91(2):76-9.

2. Stovall TG, Ling FW, Morgan PL. A prospective, randomized comparison of the Pipelle endometrial sampling device with the Novak curette. Am J Obstet Gynecol. 1991;165(5):1287-90.

3. Larson DM, Krawisz BR, Johnson KK, Broste SK. Comparison of the Z-sampler and Novak endometrial biopsy instruments for in-office diagnosis of endometrial cancer. Gynecol Oncol. 1994;54(1):64-7.

4. Rodriguez GC, Yaqub N, King ME. A comparison of the Pipelle device and the Vabra aspirator as measured by endometrial denudation in hysterectomy specimens: the Pipelle device samples significantly less of the endometrial surface than the Vabra aspirator. Am J Obstet Gynecol. 1993;168(1):55-9.

5. Naim NM, Mahdy ZA, Ahmad S, Razi ZR. The Vabra aspirator versus the Pipelle device for outpatient endometrial sampling. Aust N Z J Obstet Gynaecol. 2007;47(2):132-6.

6. Gungorduk K, Asicioglu O, Ertas IE, Ozdemir IA, Ulker MM, Yildirim G, et al. Comparison of the histopathological diagnoses of preoperative dilatation and curettage and Pipelle biopsy. Eur J Gynaecol Oncol. 2014;35(5):539-43.

7. Abdelazim IA, Aboelezz A, Abdulkareem AF. Pipelle endometrial sampling versus conventional dilatation
\& curettage in patients with abnormal uterine bleeding. J Turk Ger Gynecol Assoc. 2013;14(1):1-5.

8. Kazandi M, Okmen F, Ergenoglu AM, Yeniel AO, Zeybek B, Zekioglu O, et al. Comparison of the success of histopathological diagnosis with dilatationcurettage and Pipelle endometrial sampling. J Obstet Gynaecol. 2012;32(8):790-4.

9. Elsandabesee D, Greenwood P. The performance of Pipelle endometrial sampling in a dedicated postmenopausal bleeding clinic. J Obstet Gynaecol. 2005;25(1):32-4.

10. Du J, Li Y, Lv S, Wang Q, Sun C, Dong X, et al. Endometrial sampling devices for early diagnosis of endometrial lesions. J Cancer Res Clin Oncol. 2016;142(12):2515-22.

11. Soeters R, Whittaker J, Dehaeck K. Endometrial sampling: a comparison between the Pipelle endometrium sampler and the Endosampler. South Africa J Gynaecol Oncol. 2011;3(1):34-8.

12. Ejzenberg D, Simoes MJ, Pinheiro W, Soares JM Júnior, Serafini PC, Baracat EC. Blind aspiration biopsy versus a guided hysteroscopic technique for investigation of the endometrium in infertile women. Histol Histopathol. 2016;31(9):981-6.

13. Garuti G, Cellani F, Colonnelli M, Garzia D, Gonfiantini C, Luerti M. Hysteroscopically targeted biopsies compared with blind samplings in endometrial assessment of menopausal women taking tamoxifen for breast cancer. J Am Assoc Gynecol Laparosc. 2004;11(1):62-7.

14. Bettocchi S, Venere R, Pansini N, Pansini MV, Pellegrino A, Santamato S, Ceci O. Endometrial biopsies using small-diameter hysteroscopes and $5 \mathrm{~F}$ instruments: how can we obtain enough material for a correct histologic diagnosis? J Am Assoc Gynecol Laparosc. 2002;9(3):290-2.

15. Arumaikannu J, Priyadarsene P, Rani U. Accuracy of pipelle aspiration versus office hysteroscope in diagnosing endometrial pathology in perimenopausal women with abnormal uterine bleeding. Indian $\mathbf{J}$ of Res. 2016;5(12).

16. Kandil D, Yang X, Stockl T, Liu Y. Clinical outcomes of patients with insufficient sample from endometrial biopsy or curettage. Int $\mathbf{J}$ Gynecol Pathol. 2014;33(5):500-6.

17. Trimble CL, Method M, Leitao M, Lu K, Ioffe O, Hampton $\mathrm{M}$, et al. Management of endometrial precancers. Obstet Gynecol. 2012;120(5):1160-75.

18. Litta P, Merlin F, Saccardi C, Pozzan C, Sacco G, Fracas M, et al. Role of hysteroscopy with endometrial biopsy to rule out endometrial cancer in postmenopausal women with abnormal uterine bleeding. Maturitas. 2005;50(2):117-23.

19. Trimble CL, Kauderer J, Zaino R, Silverberg S, Lim PC, Burke JJ, et al. Concurrent endometrial carcinoma in women with a biopsy diagnosis of atypical endometrial hyperplasia: a Gynecologic Oncology Group study. Cancer. 2006;106(4):812-9.

20. Sivakumar S, Vaishnavi V. Comparartive study of endometrial sampling using Pipelle with hysteroscope 
guided biopsy. J of Evidence Based Med and Healthcare. 2017;4(53):3236-40.

21. Bakour SH, Khan KS, Gupta JK. Controlled analysis of factors associated with insufficient sample on outpatient endometrial biopsy. BJOG. 2000;107(10):1312-4.

22. Aue AA, Kleebkaow P, Kietpeerakool C. Incidence and risk factors for insufficient endometrial tissue from endometrial sampling. Int $\mathbf{J}$ Womens Health. 2018;10:453-7.

23. Visser NC, Breijer MC, Herman MC, Bekkers RL, Veersema S, Opmeer BC, et al. Factors attributing to the failure of endometrial sampling in women with postmenopausal bleeding. Acta Obstet Gynecol Scand. 2013;92(10):1216-22.

24. Breijer MC, Visser NC, Hanegem N, Wurff AA, Opmeer BC, Doorn HC, et al. A Structured
Assessment to Decrease the Amount of Inconclusive Endometrial Biopsies in Women with Postmenopausal Bleeding. Int J Surg Oncol. 2016;3039261.

25. Xie B, Qian C, Yang B, Ning C, Yao X, Du Y, et al. Risk Factors for Unsuccessful Office-Based Endometrial Biopsy: A Comparative Study of OfficeBased Endometrial Biopsy (Pipelle) and Diagnostic Dilation and Curettage. J Minim Invasive Gynecol. 2018;25(4):724-9.

Cite this article as: Zutshi V, Saran A, Ahluwalia C. Comparison of adequacy of endometrial biopsy using endosampler and hysteroscope guided sampling. Int J Reprod Contracept Obstet Gynecol 2021;10:2291-7. 